\title{
The regulating effects and mechanism of biochar and maifanite on copper and cadmium in a polluted soil-Lolium perenne L. system
}

\author{
Yuan Ding ${ }^{\text {Corresp., } 1}$, Weiya Wang ${ }^{1}$, Shiying Ao ${ }^{1}$ \\ ${ }^{1}$ College of Environmental and Chemical Engineering, Nanchang Hangkong University, Nanchang, China \\ Corresponding Author: Yuan Ding \\ Email address: 39011@nchu.edu.cn
}

Arable land polluted by copper ( $\mathrm{Cu}$ ) and cadmium ( $\mathrm{Cd}$ ) is a widespread problem. The use of biochar and/or clay mineral as a soil amendment can effectively solidify heavy metals in the soil. We applied biochar (BC), iron modified biochar (Fe-BC), maifanite (MF, a kind of clay minerals), a combination of BC with MF (BC:MF), and Fe-BC with MF (Fe-BC:MF) at a 2 wt \% dose as soil amendments to study their ability to prevent $\mathrm{Cu}$ and $\mathrm{Cd}$ from accumulating in ryegrass (Lolium perenne L.). We found that after 90 days of cultivation, the $\mathrm{Cd}$ and $\mathrm{Cu}$ content both significantly decreased in ryegrass shoots from 2.06 and 209.3 $\mathrm{mg} \mathrm{kg}^{-1}$ (control) to $1.44-2.01$ and $51.50-70.92 \mathrm{mg} \mathrm{kg}^{-1}$, respectively, across treatments $(p<0.05)$. Similarly, the bioconcentration factor (BCF) for $\mathrm{Cd} / \mathrm{Cu}$ was significantly smaller $(P<0.05)$ in all amendments versus control soil. This trend differed among the shoot, $B C F$, and transportation factor (TF). Combining BC:MF or Fe-BC:MF did not significantly improve the $\mathrm{Cd} / \mathrm{Cu}$ stabilization in the soil compared to the corresponding single amendment ( $p>$ 0.05). Our adsorption balance experiment showed that BC, Fe-BC, and MF physically and chemically adsorbed $\mathrm{Cd}$ and $\mathrm{Cu}$ by complexation with functional groups (mesoporous nanomaterials) whose porosity measurements ranged from 0.68 to $78.57 \mathrm{~m}^{2} \mathrm{~g}^{-1}$. Furthermore, the amorphous crystalline iron oxide binding $\mathrm{Cd}$ and $\mathrm{Cu}$ was the key to immobilizing these metals in the soil. The amendments applied in our study show promise for enhancing immobilization of $\mathrm{Cu}$ and $\mathrm{Cd}$ in contaminated paddy soils. 


\section{The regulating effects and mechanism of biochar and}

3 maifanite on copper and cadmium in a polluted soil-

4 Lolium perenne L. system

5 Yuan DING 1*, Weiya WANG ${ }^{1}$, Shiying AO ${ }^{1}$

6

$7{ }^{1}$ College of Environmental and Chemical Engineering, Nanchang Hangkong University,

$8 \quad$ Nanchang 330063, China

10 Corresponding Author:

11 Yuan DING

12 No. 696, Fenghe South Avenue, Nanchang, 330063, P. R. CHINA

13 Email address: 39011@nchu.edu.cn

\section{ABSTRACT}

Arable land polluted by copper $(\mathrm{Cu})$ and cadmium $(\mathrm{Cd})$ is a widespread problem. The use of biochar and/or clay mineral as a soil amendment can effectively solidify heavy metals in the soil. We applied biochar (BC), iron modified biochar (Fe-BC), maifanite (MF, a kind of clay minerals), a combination of BC with MF (BC:MF), and Fe-BC with MF (Fe-BC:MF) at a 2 wt \% dose as soil amendments to study their ability to prevent $\mathrm{Cu}$ and $\mathrm{Cd}$ from accumulating in ryegrass (Lolium perenne L.). We found that after 90 days of cultivation, the $\mathrm{Cd}$ and $\mathrm{Cu}$ content both significantly decreased in ryegrass shoots from 2.06 and $209.3 \mathrm{mg} \mathrm{kg}^{-1}$ (control) to 1.44 2.01 and 51.50 - $70.92 \mathrm{mg} \mathrm{kg}^{-1}$, respectively, across treatments $(\mathrm{p}<0.05)$. Similarly, the bioconcentration factor $(\mathrm{BCF})$ for $\mathrm{Cd} / \mathrm{Cu}$ was significantly smaller $(\mathrm{P}<0.05)$ in all amendments versus control soil. This trend differed among the shoot, BCF, and transportation factor (TF). 
Combining BC:MF or Fe-BC:MF did not significantly improve the $\mathrm{Cd} / \mathrm{Cu}$ stabilization in the soil compared to the corresponding single amendment ( $\mathrm{p}>0.05$ ). Our adsorption balance experiment showed that $\mathrm{BC}, \mathrm{Fe}-\mathrm{BC}$, and $\mathrm{MF}$ physically and chemically adsorbed $\mathrm{Cd}$ and $\mathrm{Cu}$ by complexation with functional groups (mesoporous nanomaterials) whose porosity measurements ranged from 0.68 to $78.57 \mathrm{~m}^{2} \mathrm{~g}^{-1}$. Furthermore, the amorphous crystalline iron oxide binding $\mathrm{Cd}$ and $\mathrm{Cu}$ was the key to immobilizing these metals in the soil. The amendments applied in our study show promise for enhancing immobilization of $\mathrm{Cu}$ and $\mathrm{Cd}$ in contaminated paddy soils.

\section{INTRODUCTION}

Soil pollution from heavy metals and metalloids is a worldwide concern that affects food production and human health. Anthropogenic activities, such as mining, smelting, military operations, electronic industries, fossil fuel consumption, waste disposal, agrochemical use, and irrigation are the key factors contributing to the increase of heavy metal contents in the soil (Barsova et al., 2019; Liu et al., 2018). Survey data has shown that approximately $19.4 \%$ of the total arable land in China has been polluted by various contaminants, among which $\mathrm{Cd}$ is highest (Li et al., 2019). The soil in southern China has been seriously contaminated with $\mathrm{Cu}$ and $\mathrm{Cd}$ near $\mathrm{Cu}$ smelters, resulting in large stretches of barren land. It is critical to remediate the polluted soil, restore the natural ecosystem, and protect human health.

In-situ chemical immobilization, also known as in-situ solidification/stabilization, is considered to be an inexpensive remediation method to immobilize heavy metals. This method uses chemical reagents, natural minerals, and environmentally friendly waste to decrease heavy metal mobility and phytoavailability. Although the method does not reduce the total amount of heavy metals in the soil, it does minimize the potential transportation of heavy metals from soil to plants (Song et al., 2017). The use of chemical immobilization is still an effective strategy to remediate large areas of contaminated farmland (Shen et al., 2019).

Inorganic and organic materials were used extensively in the in situ chemical immobilization of heavy metals. Clay mineral materials, such as sepiolite, smectite, zeolite, and bentonite, are the most effective inorganic amendments to adsorb heavy metals in soil. These can significantly reduce the phytoavailability of heavy metals due to their unique coordination and Si-O tetrahedron and Al-O octahedron structures' adsorption ability (Khalid et al., 2017; Sun et al., 2016). Clay minerals are advantageous in the remediation of heavy metals in soil for their low dosage and high effectiveness. However, there are risks when changing the soil's physical and chemical properties. Recent research has shown that organic amendments prepared from 
low-cost waste materials decreased the mobility or phytoavailability of heavy metals and improved the soil fertility (Li, Zhou, Qin, Tian, Qi, Yan \& Han, 2019; Quan et al., 2020). For example, biochar produced from waste biomass is a typical amendment due to their higher cation exchange capacities (CEC), chemical functional groups, microporous structure, and high $\mathrm{pH}$ (Zhai et al., 2018). In acidic soils, the ability to immobilize $\mathrm{Cd}$ and $\mathrm{Cu}$ was related to soil $\mathrm{pH}$ and the number of oxygen-containing groups on the surface of the biochar. Biochar materials were further modified in a variety of ways, such as loading iron hydroxyl group to enhance the surface adsorption capacity (Wan et al., 2020; Zhou et al., 2018).

It appears that combining clay minerals with organic amendments, such as biochar, is more suitable for treating contaminated soils. However, the immobile capacity of heavy metals varies greatly with different combinations and applications of organic and inorganic amendments. For instance, Zhang \& Ding (2019) investigated the use of hydroxyapatite, bentonite, and biochar, alone or in combination, for remediating $\mathrm{Cd}-\mathrm{Pb}$-contaminated soil. Their results showed that the largest reduction in the soluble fraction of $\mathrm{Cd}$ and $\mathrm{Pb}$ acids was observed under combined amendments. $\mathrm{Cu}$ and $\mathrm{Cd}$ 's phytoavailability and transfer mechanisms in polluted soil still need to be studied with different types, and combinations of, clay minerals and biochar.

The accumulation of heavy metals in plants, especially in the shoots, was a direct indicator of the phytoavailability of heavy metals in the soil. However, there were significant differences in amounts due to variations in plant types, as well as the effect of operability. The extraction concentration by a chemical reagent was used to indicate the phytoavailability of heavy metals. It is generally believed that the phytoavailability of $\mathrm{Cu}$ and $\mathrm{Cd}$ decreases when the weak acid soluble fraction oxidizable and transferred to residual fractions. Soil colloids are an important carrier that can render heavy metals immobile in polluted soils (Tang et al., 2020). Cu and Cd content and fractions in colloids are the key to explaining the immobilization effect and mechanism. Little attention has been paid to the influence of soil colloids on the redistribution and phytoavailability of $\mathrm{Cu}$ and $\mathrm{Cd}$ in polluted soil. We sought to (1) compare the remediation effects of different types and combinations of biochar and maifanite (a natural clay mineral); (2) understand these amendments' adsorption ability; and (3) elucidate how soil colloids remediate $\mathrm{Cu}$ and $\mathrm{Cd}$ in polluted soil.

\section{Materials \& Methods}

\section{Soil}


90 The soil samples were collected from the plough layer $(0-20 \mathrm{~cm}$ deep $)$ of a paddy field near

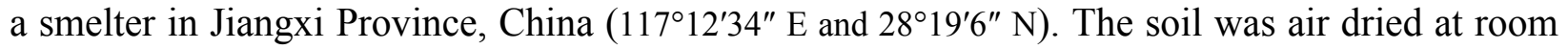
temperature and passed through a $10 \mathrm{~mm}$ sieve to remove stones and roots. The soil's basic physical and chemical properties were: $\mathrm{pH}$ : 4.96, soil organic matter (SOM): $2.0 \%$, cation exchange capacity (CEC): $68.3 \mathrm{mmol} \mathrm{kg}{ }^{-1}, \mathrm{Cu}$ concentration: $240.0 \mathrm{mg} \mathrm{kg}^{-1}, \mathrm{Cd}$ concentration: $1.93 \mathrm{mg} \mathrm{kg}^{-1}$, Fe concentration: $17.20 \mathrm{mg} \mathrm{kg}^{-1}$, available phosphorous (AP): $5.82 \mathrm{mg} \mathrm{kg}^{-1}$, and available nitrogen (AN): $141.4 \mathrm{mg} \mathrm{kg}^{-1}$.

\section{Biochar testing}

Biochar was produced from Radix isatidis (a component in traditional Chinese medicine) residue. $R$. isatidis was purchased from a pharmacy. The specific preparation method was as follows: deionized (DI) water at a ratio of $500 \mathrm{~mL}$, to which $50 \mathrm{~g}$ radix Isatidis was added and boiled for approximately $30 \mathrm{~min}$. The dregs were removed and placed in an oven at $105^{\circ} \mathrm{C}$ for 24 h. They were then dried and ground into powder in an agate bowl for later use. A laboratoryscale gas flow-controlled tube-type furnace was used to pyrolyze the $R$. isatidis dreg powder at $500{ }^{\circ} \mathrm{C}$ for $4 \mathrm{~h}$ under $\mathrm{N}_{2}$ at a flow rate of $1000 \mathrm{~mL} \mathrm{~min}^{-1}$ to produce biochar. Biochar was further pulverized to $0.25 \mathrm{~mm}$ (60 mesh) and marked as BC. The basic properties of final biochar are presented in Table 1.

\section{Modified biochar and maifanite}

We soaked 20 grams of $\mathrm{BC}$ in $1 \mathrm{~mol} \mathrm{~L}^{-1} \mathrm{FeCl}_{3}$ solution, stirred for $10 \mathrm{~min}$, let it sit for $24 \mathrm{~h}$, then filtered and dried it in an $80{ }^{\circ} \mathrm{C}$ oven. The dried $\mathrm{BC}$ was put into muffle furnace for $1 \mathrm{~h}$ at $500{ }^{\circ} \mathrm{C}$. After washing, drying, and passing through 60 mesh sieves $(0.25 \mathrm{~mm})$, the iron-modified $\mathrm{BC}$ was produced and named Fe-BC. The basic properties of Fe-BC are shown in Table 1.

Maifanite, a natural $\mathrm{SiO}_{2}$ and $\mathrm{NaAlSi}_{3} \mathrm{O}_{8}$ rich mineral, was obtained from a water purification factory using a mesh size of 60-80 (0.18 - 0.25 mm) and named MF (Table 1).

\section{Pot experiment}

Six treatments were carried out in triplicate for the pot experiment as below: (1) CK, polluted soil as control, (2) $\mathrm{BC}, \mathrm{Fe}-\mathrm{BC}, \mathrm{MF}$, biochar and maifanite $\mathrm{BC}$ : $\mathrm{MF}(1: 1, w / w)$, iron modified biochar and maifanite Fe-BC: $\mathrm{MF}(1: 1, w / w)$.

A sample of CK (2.00 kg) was completely mixed with amendments $\left(20 \mathrm{~g} \mathrm{~kg}^{-1}\right.$ soil) and 
119

120

121

122

123

124

125

126

127

128

129

130

131

132

133

134

135

136

137

138

139

140

141

142

143

144

145

146

transferred to a plastic pot (height: $15 \mathrm{~cm}$; diameter: $17 \mathrm{~cm}$ ) with deionized (DI) water in a greenhouse at $25{ }^{\circ} \mathrm{C}$. Water content was maintained at $65 \%$ of the water holding capacity. No fertilizer was applied to any treatments during the incubation period. Forty ryegrass (Lolium perenne L.) seeds were spread in each pot 40 days after cultivation. After germination, 20 seedlings remained in each pot. The shoots were cut off after 90 days. Soil colloid was extracted from the soil to analyze the fraction distribution of heavy metals after the pot experiment.

\section{Morphology and fraction distribution of amendments before and after}

\section{adsorbing $\mathrm{Cu}$ and $\mathrm{Cd}$}

$\mathrm{BC}, \mathrm{Fe}-\mathrm{BC}$ and $\mathrm{MF}$ amendments measuring $0.1 \mathrm{~g}$ each were passed through a 100 -mesh sieve placed in a $50 \mathrm{~mL}$ stoppered conical flask. Then, $20 \mathrm{~mL}$ standardized solutions of $50 \mathrm{mg} \mathrm{L}^{-}$

${ }^{1} \mathrm{Cu}$ and $\mathrm{Cd}$ were added to the flask. We added a $0.01 \mathrm{~mol} \mathrm{~L}^{-1} \mathrm{NaCl}$ solution to simulate soil conditions, followed by the addition of $0.01 \mathrm{~mol} \mathrm{~L}^{-1} \mathrm{HCl}$ and $0.01 \mathrm{~mol} \mathrm{~L}^{-1} \mathrm{NaOH}$ solutions to adjust the $\mathrm{pH}$ value to 4.96 , which was the $\mathrm{pH}$ value of the soil. Samples were kept at a constant room temperature for $24 \mathrm{~h}$ before centrifugation and filtration. The amendments were dried in an oven at $60{ }^{\circ} \mathrm{C}$ after the adsorption of $\mathrm{Cu}$ and $\mathrm{Cd}$ and crushed in an agate bowl to a particle size of 100 mesh for heavy metal morphology and fraction distribution analysis.

\section{$\mathrm{Cu}$ and $\mathrm{Cd}$ content in ryegrass (L. perenne L.)}

The air-dried ryegrass samples were ground into powder using a pulverizer to detect the heavy metal content. Next $\mathrm{Cu}$ and $\mathrm{Cd}$ content were measured using microwave digestion combined with flame-graphite furnace atomic absorption spectrometry. $\mathrm{Cu}$ and $\mathrm{Cd}$ were then measured using the FAAS/GFAAS method (GB/T 17138-1997 and GB/T 17141-1997).

\section{Fraction analysis of heavy metals in soil and soil colloid}

Soil heavy metal fraction analysis can be divided into a weak acid soluble fraction, a reducible fraction, an oxidizable fraction, and a residue fraction according to the BCR sequential extraction method. The modified BCR sequential extraction procedures were used for heavy metal fraction analysis in the soil (Zhang et al., 2019). Heavy metal fractions in soil colloid can be classified as an amorphous iron oxide bound fraction, a crystalline iron oxide bound fraction, and a residue fraction (Yin et al., 2016). 


\section{Amendment microcharacters before and after adsorption}

Modified BCR sequential extraction procedures were used for heavy metal fraction analysis in the amendments (Zhang, Shao, Zhang, Zhang \& Chen, 2019).

Amendments' specific surface area (SSA) values were measured using a Tristar II type 3020 (V1.04) analyzer (Micromeritics Instrument, USA). A scanning electron microscope (SEM, SU1510, Hitachi, Japan) was used to observe the surface morphology and microstructure. The samples were mounted on a carbon stub and were coated with Au before the examination. The crystal structures of the amendments were examined using the $\mathrm{x}$-ray diffraction analysis technique (XRD, D8 Advance X-ray diffractometer, Bruker) before and after adsorption. The surface functional groups of biochar and maifanite were determined using the Fourier transform infrared spectroscopy technique (FTIR, Vertex 70, Bruker, Germany).

\section{Calculation and statistical analysis}

The bioconcentration factor $(\mathrm{BCF})$ and the transportation factor $(\mathrm{TF})$ were calculated using the following equations (Zhang et al., 2020):

$B C F=\frac{C_{\text {shoot }}+C_{\text {root }}}{C_{\text {soil }}}$

$T F=\frac{C_{\text {shoot }}}{C_{\text {root }}}$

Where $\mathrm{C}_{\text {shoot }}$ is the metal concentration in the ryegrass shoots $\left(\mathrm{mg} \mathrm{kg}^{-1}\right), \mathrm{C}_{\text {root }}$ is the metal concentration in the root of ryegrass $\left(\mathrm{mg} \mathrm{kg}^{-1}\right)$, and $\mathrm{C}_{\text {soil }}$ is the metal concentration in the soil $\left(\mathrm{mg} \mathrm{kg}^{-1}\right)$.

The data were subjected to one-way analysis of variance (ANOVA) using SPSS software (version 23.0). Duncan's multiple range test was performed to determine the difference between treatments. Means were compared using the least significant difference test at a $p<0.05$ level of significance, and letters were used to suggest the significant variations in the data set. All of the results in the tables and figures were described as means \pm standard deviation $(n=3)$.

The precision and accuracy of heavy metal analysis were assessed through repeated analysis 
172 of the samples against National Institute of Standard and Technology, Standard Reference

173 Material (GBW07408, National Standard Detection Research Center, Beijing, China) for all the

174 heavy metals. The results were found to be within $\pm 2 \%$ of the certified value. Variations were

175 found to be less than $10 \%$.

176

177

178

179

180

181

182

183

184

185

186

187

188

189

190

191

192

193

194

195

196

197

198

199

200

201

\section{Results and Discussion}

\section{Immobilizing different amendments on $\mathrm{Cu}$ and $\mathrm{Cd}$ in soil}

\section{Effect on ryegrass}

L. perenne L. is a good indicator of heavy metal polution in soil as they are resistant to $\mathrm{Cu}$ and $\mathrm{Cd}$. Ryegrass can enter the food chain as a kind of pasture, therefore, we analyzed $\mathrm{Cu}$ and $\mathrm{Cd}$ content change in ryegrass shoots after the addition of different amendments (Fig. 1).

As shown in Fig. 1A, Cu content in shoots significantly decreased from $209.3 \mathrm{mg} \mathrm{kg}^{-1}(\mathrm{CK})$ to $51.50 \mathrm{mg} \mathrm{kg}^{-1}$ (BC), $57.90 \mathrm{mg} \mathrm{kg}{ }^{-1}$ (Fe-BC:MF), $59.29 \mathrm{mg} \mathrm{kg}^{-1}$ (BC:MF), 63.74mg kg-1 (MF), and $70.92 \mathrm{mg} \mathrm{kg}^{-1}$ (Fe-BC). Cd also decreased from $2.06 \mathrm{mg} \mathrm{kg}^{-1}(\mathrm{CK})$ to $1.43 \mathrm{mg} \mathrm{kg}^{-1}(\mathrm{MF})$, $1.46 \mathrm{mg} \mathrm{kg}^{-1}$ (BC), $1.51 \mathrm{mg} \mathrm{kg}^{-1}$ (BC:MF), $1.53 \mathrm{mg} \mathrm{kg}^{-1}$ (Fe-BC), and $2.01 \mathrm{mg} \mathrm{kg}^{-1}$ (Fe-BC:MF). $\mathrm{Cu}$ was immobilized in the following order: $\mathrm{BC}>\mathrm{Fe}-\mathrm{BC}: \mathrm{MF} \approx \mathrm{BC}: \mathrm{MF}>\mathrm{MF} \approx \mathrm{Fe}-\mathrm{BC} . \mathrm{Cu}$ content decreased by $75.4 \%, 72.3 \%, 71.7 \%, 69.6 \%$, and $66.1 \%$, respectively, compared with the control. By contrast, Cd immobilized in shoots after treatment with Fe-BC:MF did not differ significantly from the control $(\mathrm{P}>0.05)$. The treatments $\mathrm{BC}, \mathrm{Fe}-\mathrm{BC}, \mathrm{MF}$, and $\mathrm{BC}: \mathrm{MF}$ significantly reduced the $\mathrm{Cd}$ content in ryegrass shoots by $29.3 \%, 25.8 \%, 30.4 \%$, and $26.9 \%$, respectively.

The absorption of $\mathrm{Cu}$ and $\mathrm{Cd}$ in ryegrass shoot revealed the significant resistance effects of the amendments except for Fe-BC:MF. Furthermore, the resistance effect on $\mathrm{Cu}$ was much greater than on $\mathrm{Cd}$ according to the decreasing amplitude of the heavy metal content in the shoot. Our results was confirmed by Xu \& Zhao (2013), who adopted biochar to adsorb Cu(II), Cd(II) and $\mathrm{Pb}(\mathrm{II})$ in soil from southern China, and found that the complexing ability of the biochars with $\mathrm{Cu}(\mathrm{II})$ and $\mathrm{Pb}(\mathrm{II})$ was much stronger than that with $\mathrm{Cd}(\mathrm{II})$ and induced more specific adsorption of $\mathrm{Cu}(\mathrm{II})$ and $\mathrm{Pb}(\mathrm{II})$ by the soils than that of $\mathrm{Cd}(\mathrm{II})$.

The combination amendment of Fe-BC and $\mathrm{MF}$ or $\mathrm{BC}$ and $\mathrm{MF}$ did not show better advantage than the corresponding sole amendment $(\mathrm{p}>0.05)$.

\section{Effect of different amendments on BCF of $\mathrm{Cu}$ and $\mathrm{Cd}$}


202

203

204

205

206

207

208

209

210

211

212

213

214

215

216

BCF reflects the capacity of the plant as a whole (including shoot and root) to uptake $\mathrm{Cu}$ and $\mathrm{Cd}$ from the soil. This indicator is significant in plants that enter the food chain because it fully expresses the total amount of heavy metals taken up from the soil.

The $\mathrm{BCF}$ value for $\mathrm{Cu}$ and $\mathrm{Cd}$ was significantly $(\mathrm{p}<0.05)$ smaller in any amendment than that in the unamended soil (Figure 2). However, the trend and reducing amplitude of the BCF value were not consistent with the corresponding heavy metal content in the ryegrass shoot. The BCF value for $\mathrm{Cu}$ decreased from 4.82 (CK) to 2.75-3.89 (amendments). The value decreased for $\mathrm{Cd}$ from $4.92(\mathrm{CK})$ to 2.55-3.54 after the application of amendments. In addition, the best immobilization effect of the $\mathrm{BCF}$ value on $\mathrm{Cu}$ is $\mathrm{MF}$, and $\mathrm{Fe}-\mathrm{BC}$ of $\mathrm{Cd}$, among the amendments.

\section{Different amendments' effects on TF of $\mathrm{Cu}$ and $\mathrm{Cd}$}

The content of $\mathrm{Cu}$ and $\mathrm{Cd}$ in ryegrass shoots was inconsistent with the corresponding value of BCF. This effect may be due to the varying transfer capacity of $\mathrm{Cu}$ and $\mathrm{Cd}$ from root to shoot after being treated with different amendments. The changes in $\mathrm{Cu}$ and $\mathrm{Cd}$ with the transportation factor (TF) are shown in Fig 3.

TF is an important indicator of the transportation of heavy metals in plant tissues (Zhang et al., 2020). Fig. 3A shows that the TF value of $\mathrm{Cu}(0.07-0.11)$ was significantly smaller than that of the control group (0.22), indicating that the transfer ability of $\mathrm{Cu}$ from the root to the shoot also decreased after the application of the amendment. However, the TF value of $\mathrm{Cd}(0.28-0.50)$ was significantly larger than that of the control group (0.28) (Fig. 3B).

As an essential element, copper is beneficial to the environment in trace quantities and be poisonous at high concentration. However, the total $\mathrm{Cu}$ content in the soil $\left(239.98 \mathrm{mg} \mathrm{kg}^{-1}\right)$ in our study was so high that ryegrass exerted a self-protection mechanism to prevent $\mathrm{Cu}$ transfer from root to shoot, even after amendments were applied to decrease its phytoavailability (Ali et al., 2017). Therefore, the value of BCF and TF of copper was still less than the control after the application of amendments.

Cadmium is a non-essential element for plant growth and shows carcinogenicity. A high content of $\mathrm{Cd}$ would inhibit plant growth or even cause death, but low content would promote plant growth. Low amounts of $\mathrm{Cd}$ in the soil will also promote $\mathrm{Cd}$ transport from root to shoot. Limited Cd content $\left(0.30 \mathrm{mg} \mathrm{kg}^{-1}\right)$ in China's soil environmental quality standard (GB 156182018) is within the range required to promote plant growth and absorption. Research has shown that $\mathrm{Cd}$ content in test plant such as rice and peanuts is higher than food hygiene standards, while the soil Cd content is lower than the soil standard (Gallego et al., 2012). In the same way, the 
234 bioavailable $\mathrm{Cd}$ content after immobilization may be within a range that is easily transferred and 235 absorbed by plants. This may be the reason that the TF of cadmium treated with the amendments 236 increased in our study.

237

238

239

\section{Microscopic characteristics of amendments and its interaction} mechanism with $\mathrm{Cu}$ and $\mathrm{Cd}$

\section{Micromorphology and specific surface area of amendments}

As described above, the sole amendment by $\mathrm{BC}, \mathrm{Fe}-\mathrm{BC}, \mathrm{MF}$ and their combinations clearly immobilized $\mathrm{Cd}$ and $\mathrm{Cu}$ in polluted soil. We determined the amendments' micromorphology and the fraction distribution of $\mathrm{Cd}$ and $\mathrm{Cu}$ in the amendments and soil colloid. This illuminates the microcharacteristic differences of these amendments (BC, Fe-BC, MF) and its immobilization of $\mathrm{Cd}$ and $\mathrm{Cu}$.

The three amendments' morphologies were examined with SEM. The BC amendment showed an irregular microstructure with an uneven surface and dense distribution of pore channels (Fig. 4A). Tiny particles attached to Fe-BC's surface may be iron oxides (Fig. 4B), which was consistent with the data in Table 1 . The content of iron increased from $4.66 \mathrm{~g} \mathrm{~kg}^{-1}$ to $172.9 \mathrm{~g} \mathrm{~kg}^{-1}$ after being modified by iron salt. The iron oxides on the surface of the biochar may be $\mathrm{Fe}_{3} \mathrm{O}_{4}$ or $\alpha-\mathrm{FeOOH}$, which provide abundant active hydroxyl groups for biochar (Zhu et al., 2019). The MF amendment (Fig. 3C) revealed a distinct layered structure and a large number of granular particles attached to its surface.

In addition to SEM, BET was also used to determine the specific surface area (SSA) of the materials. The results showed that all of the studied amendments belonged to mesoporous nanomaterials with SSA values at the range of 0.68-78.57 $\mathrm{m}^{2} \mathrm{~g}^{-1}$ (Table 1). The highest SSA value was detected in $\mathrm{Fe}-\mathrm{BC}$, indicating that $\mathrm{Fe}-\mathrm{BC}$ could provide more adsorption of $\mathrm{Cu}$ and $\mathrm{Cd}$ than others.

\section{Functional groups of amendments before and after adsorption of $\mathrm{Cu}$} and Cd

We analyzed the variations of the functional groups of the amendments before and after $\mathrm{Cu}$ and $\mathrm{Cd}$ adsorption using the FTIR spectroscopy technique (Fig. 5). The wide absorption peaks at 
262

263

264

265

266

267

268

269

270

271

272

273

274

275

276

277

278

279

280

281

282

283

284

285

286

287

288

289

290

291

292

293

294

$1,110 \mathrm{~cm}^{-1}$ were characteristic of the thermal degradation of lignocellulosic biomass, mainly generated by the vibrations caused by the expansion of $\mathrm{C}-\mathrm{O}$ bonds (Wu et al., 2018). There was almost no change noted in the characteristic peaks of Fe modified/unmodified biochar after the adsorption of heavy metals (Fig. 5A), indicating that there was limited damage made to the lignocellulosic structure.

The surface functional groups of BC detected at $1,700 \mathrm{~cm}^{-1}, 1,560 \mathrm{~cm}^{-1}$, and $1,380 \mathrm{~cm}^{-1}$ were assigned to the carbonyl $\left(\mathrm{C}=\mathrm{O}\right.$ ) (Wang et al., 2014). The $\mathrm{C}=\mathrm{C}$ bending vibration, $\mathrm{CH}_{3}$ bending vibrations (Hao et al., 2021), and the hydroxyl (-OH) appeared at 1,420 $\mathrm{cm}^{-1}$ and 617 $\mathrm{cm}^{-1}$ (Bueno \& Morgado, 1993; Mitić et al., 2009). The results demonstrated that the surface of the biochar from medicine residue included oxygen-containing functional groups, such as carboxyl, lactone, carbonyl, and hydroxyl. The strength of the framework-stretching vibration absorption peak of $\mathrm{C}=\mathrm{O}$ in the aromatic ring at $1,700 \mathrm{~cm}^{-1}$ decreased after the adsorption of $\mathrm{Cu}$ and $\mathrm{Cd}$. The characteristic peak for the $-\mathrm{OH}$ functional group of $\mathrm{BC}$ decreased at $1,420 \mathrm{~cm}^{-1}$, indicating that the hydroxyl groups possibly on the surface of the biochar may participate in the adsorption reaction process of $\mathrm{Cu}$ and $\mathrm{Cd}$. Consequently, the $\mathrm{BC}$ surface, a type of porous material with the oxygen-containing functional groups mentioned above, was involved in the adsorption reaction process of $\mathrm{Cu}$ and $\mathrm{Cd}$.

The absorption peak of $\mathrm{CH}_{3}$ bending vibrations at $1,380 \mathrm{~cm}^{-1}$ for $\mathrm{Fe}-\mathrm{BC}$ was stronger than $\mathrm{BC}$ when comparing $\mathrm{BC}$ with $\mathrm{Fe}-\mathrm{BC}$ before adsorption. The $\mathrm{C}=\mathrm{O}$ absorption peak $\left(1,700 \mathrm{~cm}^{-1}\right)$, and $-\mathrm{OH}$ bending vibration peak $\left(1,420 \mathrm{~cm}^{-1}\right.$ and $\left.617 \mathrm{~cm}^{-1}\right)$ for $\mathrm{Fe}-\mathrm{BC}$ practically disappeared. The absorption peak of Fe-OH at $796 \mathrm{~cm}^{-1}$ appeared (Chen et al., 2020), which is a characteristic peak for iron oxide, signaling that Fe was attaching on the surface of the biochar. The absorption peak at $796 \mathrm{~cm}^{-1}$ and $1,380 \mathrm{~cm}^{-1}$ significantly weakened after the adsorption of heavy metals with Fe-BC, implying that $\mathrm{Fe}-\mathrm{OH}$ and $-\mathrm{CH}_{3}$ participated in the reaction process.

In addition, the FTIR spectra of Fe-BC samples (Fig. 5A) and maifanite samples after adsorption of $\mathrm{Cu}$ and $\mathrm{Cd}$ (Fig. 5B) showed a vibration peak of $-\mathrm{OH}$ group related to water at $3,380 \mathrm{~cm}^{-1}$ or $3,450 \mathrm{~cm}^{-1}$. Moisture was unavoidable in the experiments.

MF is rich in quartz, feldspar, and smectite, as aforementioned. The stretching vibrational peak corresponding to $\mathrm{C}=\mathrm{O}$ and can be detected at a wavenumber of $1,800 \mathrm{~cm}^{-1}$, and the bending vibration peak of $\mathrm{H}-\mathrm{O}-\mathrm{H}$ at $1,630 \mathrm{~cm}^{-1}$. The stretching vibration absorption peak of Si-OH was detected at $1,030 \mathrm{~cm}^{-1}$. The FTIR absorption peaks intensities weakened after $\mathrm{Cu}$ and $\mathrm{Cd}$ adsorption, indicating the main components participated in the adsorption of heavy metals (Zhang et al., 2012).

Peer] reviewing PDF | (2021:02:58539:1:0:NEW 9 Jul 2021) 
295 X-ray diffraction analysis of amendments before and after adsorption

296 Carbon was a main component in the biochar produced from the medicine residue of radix 297 Isatidis. Patterns of XRD in Fig. 6A reveal a wide and slow diffusion peak in the range of $22^{\circ}-36^{\circ}$ 298 for C (002), which is typically caused by the lamination of single atomic carbon layers in microcrystals. Moreover, C (101) of cellulose characteristic crystal plane diffraction peaks with relatively wide but small intensity was observed in the range of $12^{\circ}-15^{\circ}$. We also detected characteristic peaks from $\mathrm{SiO}_{2}$ at $26.48^{\circ}, \mathrm{CaCO}_{3}$ at $29.56^{\circ}$ and $43^{\circ}$, and $\mathrm{CaMg}\left(\mathrm{CO}_{3}\right)_{2}$ at $30.8^{\circ}$ when comparing the resulting patterns with the standard pdf cards. The results showed the presence of $\mathrm{SiO}_{2}, \mathrm{CaCO}_{3}$, and $\mathrm{CaMg}\left(\mathrm{CO}_{3}\right)_{2}$ on the biochar surface when the biochar was formed in the process of gasification evaporation. Our results are similar to those of Wang et al. (2017), which detected alkaline salts, such as $\mathrm{KCl}, \mathrm{CaCO}_{3}$, and $\mathrm{MgCl}_{2}$ in the biochar extracted from water hyacinth and maize straw.

There were no clear changes in diffraction peak positions after the adsorption of $\mathrm{Cu}$ and $\mathrm{Cd}$ in $\mathrm{BC}$ were observed. $\mathrm{C}, \mathrm{SiO}_{2}, \mathrm{CaCO}_{3}$, and $\mathrm{CaMg}\left(\mathrm{CO}_{3}\right)_{2} \mathrm{SiO}_{2}$ did not participate in $\mathrm{Cu}$ and $\mathrm{Cd}$ reactions. In addition, $\mathrm{Cu}^{2+}$ and $\mathrm{Cd}^{2+}$ were adsorbed on the surface of biochar with organic groups, such as hydroxyl, carboxyl, lactone, and carbonyl. We detected characteristic peaks of $\mathrm{C}$, $\mathrm{SiO}_{2}, \mathrm{CaCO}_{3}$, and $\mathrm{CaMg}\left(\mathrm{CO}_{3}\right)_{2} \mathrm{SiO}_{2}$ as well as magnetite in the X-ray diffraction pattern of Fe$\mathrm{BC}$ (Fig. 6A). This observation indicates that the iron oxide loaded to $\mathrm{BC}$ might be magnetite.

The XRD peaks of maifanite after the adsorption of $\mathrm{Cu}$ and $\mathrm{Cd}$ (Fig. 6B) reveal the presence of $\mathrm{SiO}_{2}, \mathrm{CaCO}_{3}, \mathrm{NaAlSi}_{3} \mathrm{O}_{8}$ (sodium feldspar), and $\mathrm{Al}_{2} \mathrm{Si}_{2} \mathrm{O}_{5}(\mathrm{OH})_{4}$ (smectite). The absorption peaks of smectite at $10.4^{\circ}$ and $12.3^{\circ}$ disappeared after adsorption of $\mathrm{Cu}$ and $\mathrm{Cd}$. The absorption peaks of sodium feldspar at $8.75^{\circ}, 13.8^{\circ}$, and $27.3^{\circ}$ also weakened or disappeared completely as a result of $\mathrm{Cu}$ and $\mathrm{Cd}$ adsorption. These results indicate that the silica hydroxyl, hydroxyl, and carboxyl groups on the surface of sodium feldspar and smectite in maifanite participate in the adsorption of $\mathrm{Cu}$ and $\mathrm{Cd}$. Analyses of SEM, FTIR, and XRD in the immobilization process are consistent.

Extraction fraction of heavy metals from amendments

$\mathrm{BC}, \mathrm{Fe}-\mathrm{BC}$, and $\mathrm{MF}$ are mesoporous nanomaterials, which physically adsorbed $\mathrm{Cu}$ and $\mathrm{Cd}$ and generated a chemical complexation with functional groups on their surfaces. This affected the extraction fraction percentage of $\mathrm{Cu}$ and $\mathrm{Cd}$ across amendments.

The modified BCR sequential extraction method was used to analyze the $\mathrm{Cu}$ and $\mathrm{Cd}$ fraction from the amendments after adsorption (Fig. 7). The weak acid soluble fractions of $\mathrm{Cu}$ in 
327

328

329

330

331

332

333

334

335

336

337

338

339

340

341

342

343

344

345

346

347

348

349

350

351

352

353

354

355

356

357

358

359

MF, BC, and Fe-BC were 91.10\%, 41.06\%, and 52.65\%, respectively. The reducible fractions of $\mathrm{Cu}$ were $1.59 \%, 10.03 \%$, and $9.65 \%$, respectively. The oxidizable fractions of $\mathrm{Cu}$ were $0.08 \%$, $15.00 \%$, and $11.98 \%$, respectively, and the residual fractions of $\mathrm{Cu}$ were $7.23 \%, 33.92 \%$, and $25.72 \%$, respectively, after the adsorption equilibrium experiment. The residual fraction $\mathrm{Cu}$ in balanced $\mathrm{MF}$ with $\mathrm{Cu}$ and $\mathrm{Cd}$ solution was significantly lower than that in balanced $\mathrm{BC}$ and balanced $\mathrm{Fe}-\mathrm{BC}$, which was inconsistent with the results in treated soil. The residual fraction $\mathrm{Cu}$ in soil treated with MF was the highest among all of the amend treatments (Fig S1). The $\mathrm{pH}$ of the solution in the adsorption balance experiment was affected by the amendments. The $\mathrm{pH}$ of MF (7.03) was neutral and lower than that of BC (10.93) and Fe-BC (8.44) (Table 1). The immobile effect of MF on heavy metals was worse than that of $\mathrm{BC}$ and $\mathrm{Fe}-\mathrm{BC}$. The soil $\mathrm{pH}$ was 6.30, 5.99 and 5.77, respectively, after being treated with the test amendments. The change of $\mathrm{pH}$ in test soils was not consistent with the solution, in which MF increased the soil $\mathrm{pH}$ most significantly. Thus the increase in heavy metal residual fraction in the soil was the most significant among the three amendments.

The weak acid soluble fractions of $\mathrm{Cd}$ in $\mathrm{MF}, \mathrm{BC}$, and $\mathrm{Fe}-\mathrm{BC}$ were $97.24 \%, 86.14 \%$, and $84.38 \%$. The reducible fractions of $\mathrm{Cd}$ were $0.48 \%, 12.09 \%$, and $13.18 \%$. The oxidizable $\mathrm{Cd}$ fractions were undetected. The residual fractions of $\mathrm{Cd}$ were $2.28 \%, 1.16 \%$ and $1.82 \%$, respectively, after the adsorption equilibrium between amendments and the $\mathrm{Cu}, \mathrm{Cd}$ solution (Fig. 7B). The residual fractions of heavy metals in soil were generally not absorbed by the plants. The residual fraction of $\mathrm{Cu}$ in all treatments was far higher than $\mathrm{Cd}$, indicating that the immobile effect of the three amendments on $\mathrm{Cu}$ was better than that on $\mathrm{Cd}$. These results are consistent with the content of $\mathrm{Cu}$ and $\mathrm{Cd}$ in ryegrass after treatment.

\section{Extraction fraction of heavy metals from soil colloid with amendments}

The heavy metals and the soil colloid interacted with the amendment in the soil environment. Soil colloids are the basic soil functional unit carrying heavy metals due to its small particle size, larger SSA and negative charge. It was also a key factor affecting the distribution of heavy metals in the soil. Therefore, the total content of $\mathrm{Cu}$ and $\mathrm{Cd}$ in colloids was much higher than that in the soil (Table 2). For example, the content of $\mathrm{Cu}$ and $\mathrm{Cd}$ in untreated polluted soil colloids was $489.92 \mathrm{mg} \mathrm{kg}^{-1}$ and $2.57 \mathrm{mg} \mathrm{kg}^{-1}$, respectively, which was 2.04 and 1.33 times that of soil $\mathrm{Cu}\left(239.98 \mathrm{mg} \mathrm{kg}^{-1}\right)$ and $\mathrm{Cd}\left(1.93 \mathrm{mg} \mathrm{kg}^{-1}\right)$. The accumulation effect on $\mathrm{Cu}$ is greater than Cd in colloid.

Heavy metals in soil colloids can be divided into an amorphous iron oxide bound fraction, a crystal iron oxide bound fraction and a residual bound fraction. It is well known that the increase 
360 of the amorphous iron oxide bound fraction signals the decrease in the phytoavailability of heavy 361 metals. The forms of $\mathrm{Cu}$ and $\mathrm{Cd}$ in the soil colloid after treated with $\mathrm{MF}, \mathrm{BC}$ and Fe-BC were all 362 relocated (Figure 8). Compared with the CK treatment, the content of amorphous/non-crystalline 363 iron oxide-bond $\mathrm{Cu}$ in colloids after immobilization treatments increased significantly by $20.34 \%$, $36416.81 \%$, and $18.87 \%$, respectively. The content of residual bond $\mathrm{Cu}$ decreased significantly by $36520.23 \%, 17.01 \%$, and $19.17 \%$, respectively. Non-crystalline iron oxide bond Cd content 366 increased significantly by $3.72 \%, 4.18 \%$, and $6.58 \%$, respectively, and the residual bond $\mathrm{Cd}$ 367 decreased significantly by $3.65 \%, 4.57 \%$, and $7.04 \%$, respectively. The variation in the 368 crystalline iron oxide bond of $\mathrm{Cu}$ or $\mathrm{Cd}$ was not significant. The effect of amendments on $\mathrm{Cu}$ was 369 greater than $\mathrm{Cd}$. Moreover, soil endogenetic minerals and organic matter may participate in the 370 immobilization process, affecting the redistribution of heavy metals in the soil and soil colloid.

\section{Conclusions}

The studied amendments, BC, Fe-BC, MF, BC:MF(1:1), and Fe-BC:MF(1:1), effectively immobilized copper and cadmium, and the types and combinations of BC and MF used affected $\mathrm{Cu}$ and $\mathrm{Cd}$ differently. Amendments were better able to immobilize $\mathrm{Cu}$ than $\mathrm{Cd}$. The $\mathrm{Cu}$ content in shoots significantly decreased from $209.3 \mathrm{mg} \mathrm{kg}^{-1}$ (CK) to $51.50 \mathrm{mg} \mathrm{kg}^{-1}$ (BC), $57.90 \mathrm{mg} \mathrm{kg}^{-1}$ (Fe-BC:MF), $59.29 \mathrm{mg} \mathrm{kg}^{-1}$ (BC:MF), 63.74mg kg-1 (MF), and $70.92 \mathrm{mg} \mathrm{kg}^{-1}$ (Fe-BC). Meanwhile, the $\mathrm{Cd}$ content decreased from $2.06 \mathrm{mg} \mathrm{kg}^{-1}(\mathrm{CK})$ to $1.43 \mathrm{mg} \mathrm{kg}^{-1}(\mathrm{MF}), 1.46 \mathrm{mg} \mathrm{kg}^{-}$ ${ }^{1}$ (BC), $1.51 \mathrm{mg} \mathrm{kg}^{-1}$ (BC:MF), $1.53 \mathrm{mg} \mathrm{kg}^{-1}$ (Fe-BC), and $2.01 \mathrm{mg} \mathrm{kg}^{-1}$ (Fe-BC:MF).

BC, Fe-BC, and MF may physically adsorb copper and cadmium. They may also generate chemical complexation with functional groups which could then affect the extraction fraction percentage of $\mathrm{Cu}$ and $\mathrm{Cd}$ in the amendments. The content of amorphous crystalline iron oxide bound $\mathrm{Cu}$ in colloid was higher than $\mathrm{Cd}$, and was a key step to immobilization.

The studied amendments can be used to enhance the immobilization of copper and cadmium in the contaminated paddy soils. The immobilization effects of the amendments depended on the metal element and combination of amendments. The suitable amendment method outlined in this research may be used to prevent the contamination of heavy metals in soils, especially $\mathrm{Cu}$ and $\mathrm{Cd}$.

\section{References}

Ali A, Guo D, Zhang Y, Sun X, Jiang S, Guo Z, Huang H, Liang W, Li R, and Zhang Z. 
390

391

392

393

394

395

396

397

398

399

400

401

402

403

404

405

406

407

408
2017. Using bamboo biochar with compost for the stabilization and phytotoxicity reduction of heavy metals in mine-contaminated soils of China. Scientific Reports 7:2690.

Barsova N, Yakimenko O, Tolpeshta I, and Motuzova G. 2019. Current state and dynamics of heavy metal soil pollution in Russian Federation-A review. Environmental Pollution 249:200207.

Bueno WA, and Morgado F. 1993. Hydrogen bonding of adenine with benzoic acids in the solid state. An FTIR study. Spectrochimica Acta Part A: Molecular Spectroscopy 49:249-256.

Chen M, Lu G, Wu J, Sun J, Yang C, Xie Y, Wang K, Deng F, Yi X, and Dang Z. 2020. Acidity and metallic elements release from AMD-affected river sediments: Effect of AMD standstill and dilution. Environmental Research 186:109490.

Gallego SM, Pena LB, Barcia RA, Azpilicueta CE, Iannone MF, Rosales EP, Zawoznik MS, Groppa MD, and Benavides MP. 2012. Unravelling cadmium toxicity and tolerance in plants: Insight into regulatory mechanisms. Environmental \& Experimental Botany 83:33-46.

Hao N, Cao J, Ye J, Zhang C, Li C, and Bate B. 2021. Content and morphology of lead remediated by activated carbon and biochar: A spectral induced polarization study. Journal of Hazardous Materials 411:124605.

Khalid S, Shahid M, Niazi NK, Murtaza B, Bibi I, and Dumat C. 2017. A comparison of technologies for remediation of heavy metal contaminated soils. Journal Of Geochemical Exploration 182:247-268. 

Heavy Metals Contamination in Soil: Effects, Sources, and Remediation Techniques. Soil \& Sediment Contamination 28:380-394.

Liu LW, Li W, Song WP, and Guo MX. 2018. Remediation techniques for heavy metalcontaminated soils: Principles and applicability. Science Of the Total Environment 633:206-219. characterization of $\mathrm{Cu}(\mathrm{II})$ coordination compounds with exopolysaccharide pullulan and its derivatives. Journal of Molecular Structure 924-926:264-273. Environment International 105:43-55. 
effectiveness of sepiolite, bentonite, and phosphate amendments on the stabilization remediation of cadmium-contaminated soils. Journal Of Environmental Management 166:204-210.

Tang XY, Katou H, and Suzuki K. 2020. Liming effects on dissolved and colloid-associated transport of cadmium in soil under intermittent simulated rainfall. Journal of Hazardous Materials 400:123244.

Wan X, Li C, and Parikh SJ. 2020. Simultaneous removal of arsenic, cadmium, and lead from soil by iron-modified magnetic biochar. Environmental Pollution 261:114-157.

Wang H, Xia W, Lu P, Bu Y, and Yang H. 2017. Adsorption characteristics of biochar on heavy metals ( $\mathrm{Pb}$ and $\mathrm{Zn})$ in soil. Environmental Science 38:3944-3952.

Wang S, Lin H, Ru B, Sun W, Wang Y, and Luo Z. 2014. Comparison of the pyrolysis behavior of pyrolytic lignin and milled wood lignin by using TG-FTIR analysis. Journal of Analytical and Applied Pyrolysis 108:78-85.

Wu X, Ba Y, Wang X, Niu M, and Fang K. 2018. Evolved gas analysis and slow pyrolysis mechanism of bamboo by thermogravimetric analysis, Fourier transform infrared spectroscopy and gas chromatography-mass spectrometry. Bioresource Technology 266:407-412.

$\mathrm{Xu} \mathrm{R}$, and Zhao A. 2013. Effect of biochars on adsorption of $\mathrm{Cu}(\mathrm{II}), \mathrm{Pb}(\mathrm{II})$ and $\mathrm{Cd}(\mathrm{II})$ by three variable charge soils from southern China. Environmental Science and Pollution Research 20:8491-8501. 
446

447

448

450
Yin H, Tan N, Liu C, Wang J, Liang X, Qu M, Feng X, Qiu G, Tan W, and Liu F. 2016. The associations of heavy metals with crystalline iron oxides in the polluted soils around the mining areas in Guangdong Province, China. Chemosphere 161:181-189.

Zhai X, Li Z, Huang B, Luo N, Huang M, Zhang Q, and Zeng G. 2018. Remediation of multiple heavy metal-contaminated soil through the combination of soil washing and in situ immobilization. Science of the Total Environment 635:92-99.

Zhang D, and Ding A. 2019. Effects of Passivating Agents on the Availability of $\mathrm{Cd}$ and $\mathrm{Pb}$ and Microbial Community Function in a Contaminated Acidic Soil. Bulletin of Environmental Contamination and Toxicology 103:98-105.

Zhang H, Shao J, Zhang S, Zhang X, and Chen H. 2019. Effect of Phosphorus-Modified Biochars on Immobilization of Cu (II), Cd (II), and As (V) in Paddy Soil. Journal of Hazardous Materials 390:121349.

Zhang L, Luo L, and Zhang S. 2012. Integrated investigations on the adsorption mechanisms of fulvic and humic acids on three clay minerals. Colloids and Surfaces A 406:84-90.

Zhang S, Gong X, Shen Z, Yuan S, and Wang G. 2020. Study on Remediation of CdContaminated Soil by Thermally Modified Attapulgite Combined with Ryegrass. Soil and Sediment Contamination 29:1-22.

Zhou X, Liu Y, Zhou J, Guo J, Ren J, and Zhou F. 2018. Efficient removal of lead from aqueous solution by urea-functionalized magnetic biochar: Preparation, characterization and 
mechanism study. Journal of the Taiwan Institute of Chemical Engineers 91:457-467. 


\section{Table $\mathbf{1}$ (on next page)}

Basic properties of biochar and maifanite

BC: biochar from medicine residue, Fe-BC: iron modified biochar, MF: maifanite. "ND" indicates undetected or below the detection limit. Values were described as means \pm standard deviation $(n=3)$. 
1 Table 1 Basic properties of biochar and maifanite\#

\begin{tabular}{|c|c|c|c|c|c|c|}
\hline Treatment & $\mathrm{pH}$ & $\mathrm{Cu} / \mathrm{mg} \mathrm{kg}^{-1}$ & $\mathrm{Cd} / \mathrm{mg} \mathrm{kg}^{-1}$ & $\mathrm{Fe} / \mathrm{g} \mathrm{kg}^{-1}$ & ash content $/ \%$ & $\mathrm{SSA} / \mathrm{m}^{2} \mathrm{~g}^{-1}$ \\
\hline $\mathrm{BC}$ & $10.93 \pm 0.09$ & $18.49 \pm 0.59$ & ND & $4.66 \pm 0.51$ & $13.73 \pm 0.62$ & 9.45 \\
\hline $\mathrm{Fe}-\mathrm{BC}$ & $8.44 \pm 0.03$ & $26.80 \pm 0.94$ & ND & $172.9 \pm 5.0$ & $26.24 \pm 1.26$ & 78.57 \\
\hline MF & $7.03 \pm 0.18$ & $12.89 \pm 0.53$ & ND & ND & ND & 0.68 \\
\hline
\end{tabular}

2 Notes.

3 BC: biochar from medicine residue, Fe-BC: iron modified biochar, MF: maifanite. "ND" indicates undetected or below the 4 detection limit. Values were described as means \pm standard deviation $(n=3)$.

5 
Table 2 (on next page)

Effect of amendments on the content of $\mathrm{Cu}$ and $\mathrm{Cd}$ in soil colloid. 
1 Table 2 Effect of amendments on the content of $\mathrm{Cu}$ and $\mathrm{Cd}$ in soil colloid.

\begin{tabular}{ccccc}
\hline treatment & CK & MF & BC & Fe-BC \\
\hline $\mathrm{Cu} / \mathrm{mg}^{\mathrm{kg}} \mathrm{kg}^{-1}$ & $489.9 \pm 8.4 \mathrm{a}$ & $488.1 \pm 11.4 \mathrm{a}$ & $500.5 \pm 24.2 \mathrm{a}$ & $471.0 \pm 8.8 \mathrm{a}$ \\
$\mathrm{Cd} / \mathrm{mg}^{\mathrm{kg}} \mathrm{kg}^{-1}$ & $2.57 \pm 0.04 \mathrm{~b}$ & $2.17 \pm 0.23 \mathrm{a}$ & $2.35 \pm 0.53 \mathrm{a}$ & $1.98 \pm 0.06 \mathrm{a}$ \\
\hline
\end{tabular}


Figure 1

$\mathrm{Cu}(\mathrm{A})$ and $\mathrm{Cd}(\mathrm{B})$ content in shoot of ryegrass treated with different amendments.

The data shown here was the averages of three replicates with the standard error indicated by the vertical bars. Different lowercase letters in each column represented statistically significant differences among treatments $(\mathrm{P}<0.05)$.
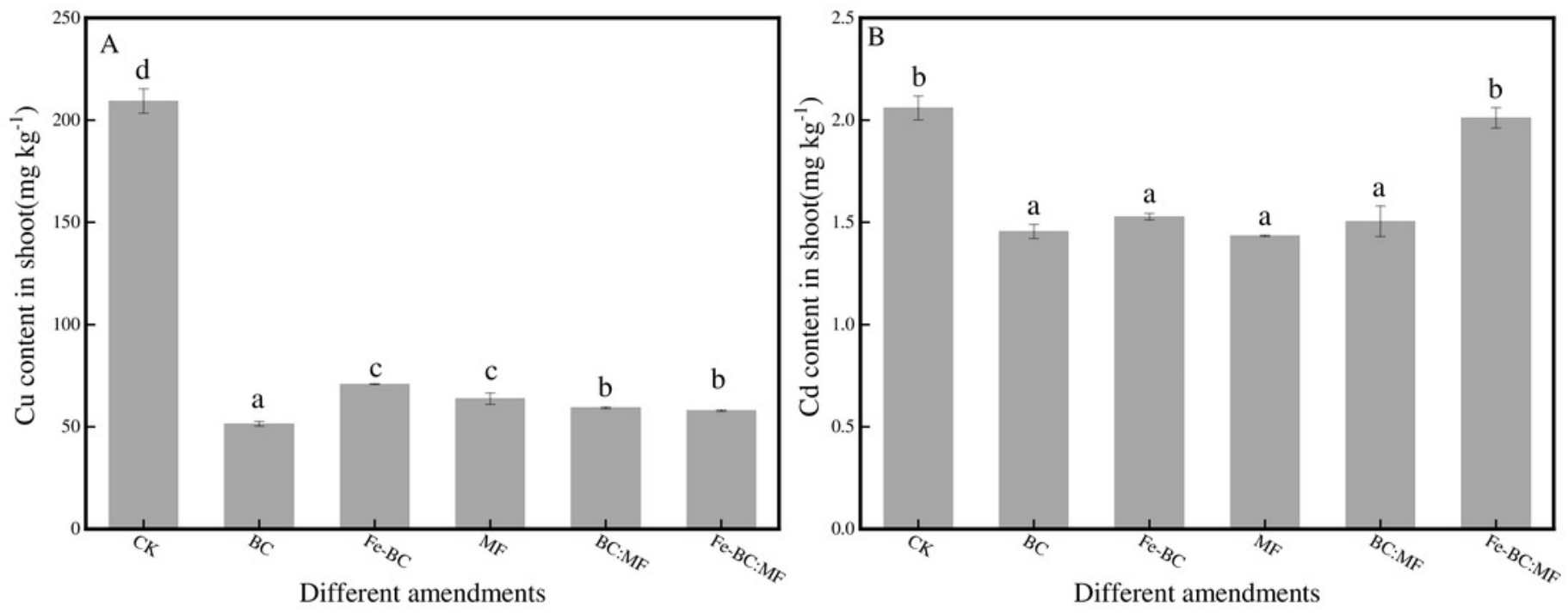
Figure 2

Effects of different amendments on BCF of $\mathrm{Cu}$ and $\mathrm{Cd}(\mathrm{A}$ and $\mathrm{B})$.
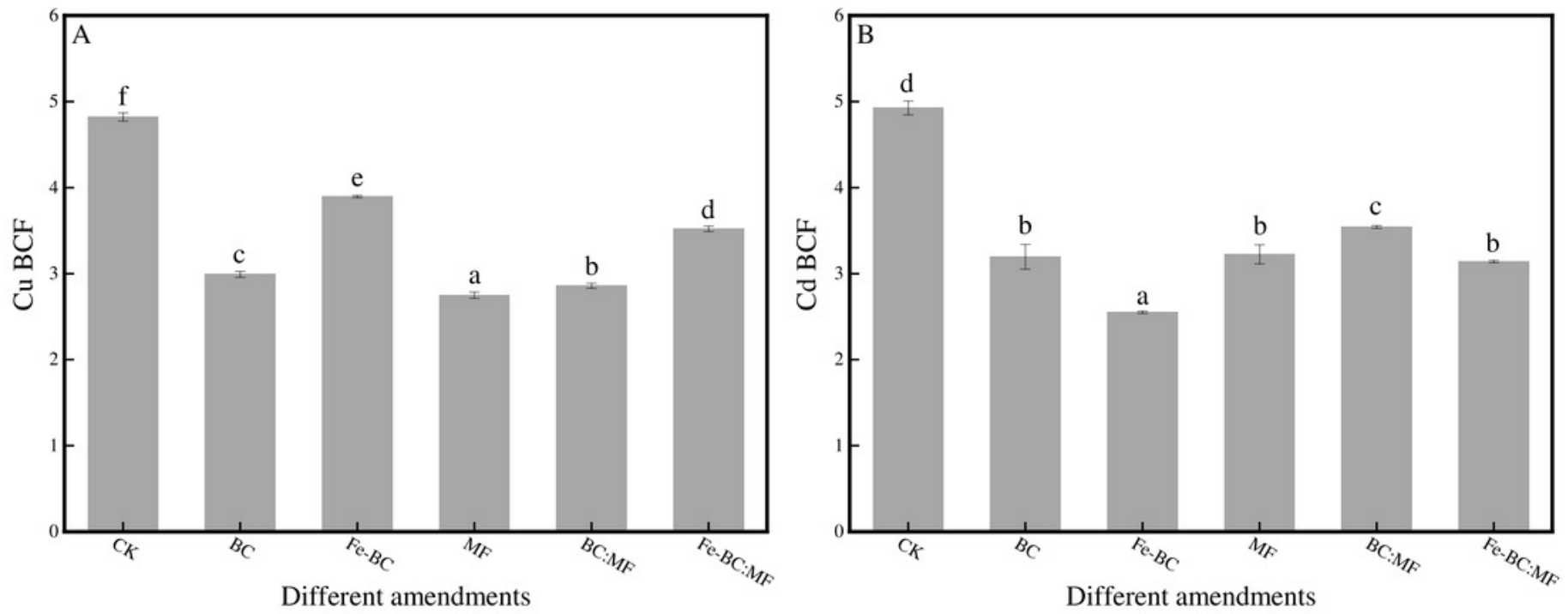
Figure 3

Effects of different amendments on transportation factor for $\mathrm{Cu}(\mathrm{A})$ and $\mathrm{Cd}(\mathrm{B})$.

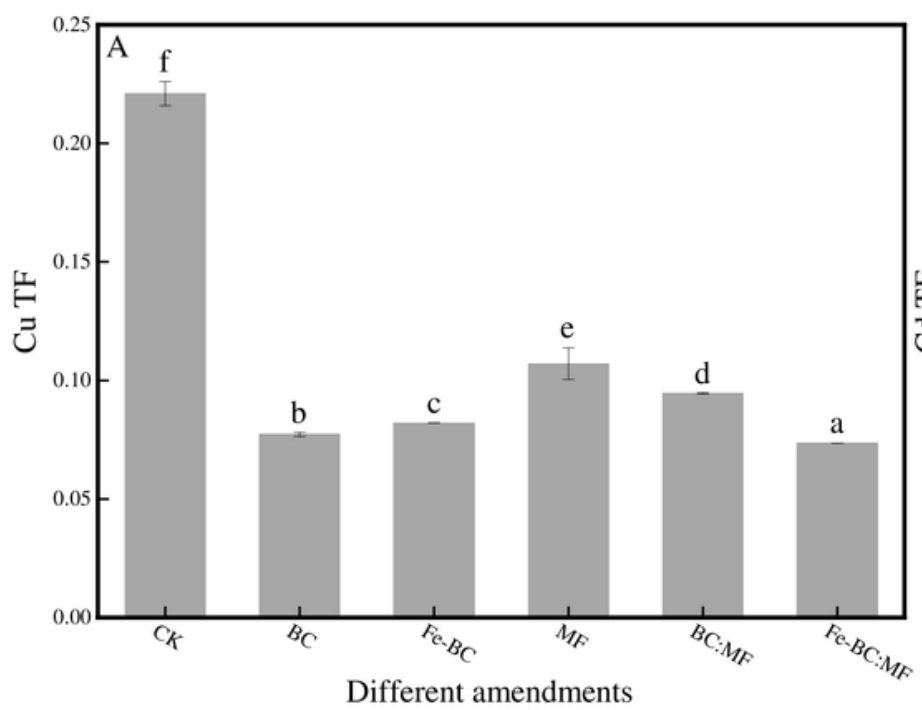

Different amendments

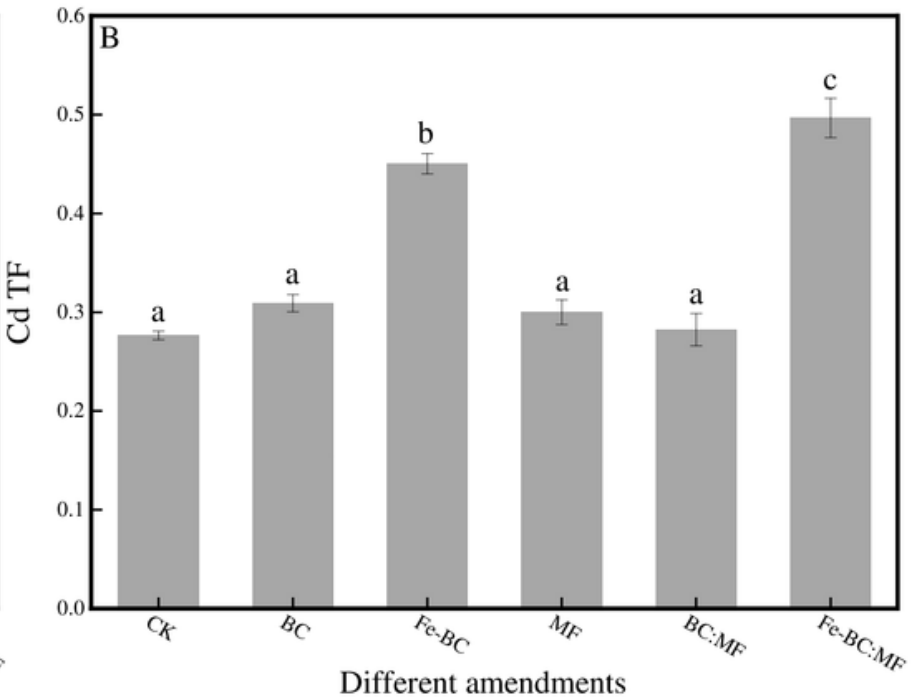


Figure 4

Scanning electron microscopy (SEM) micrographs of amendments BC (A), Fe-BC (B), and MF (C).

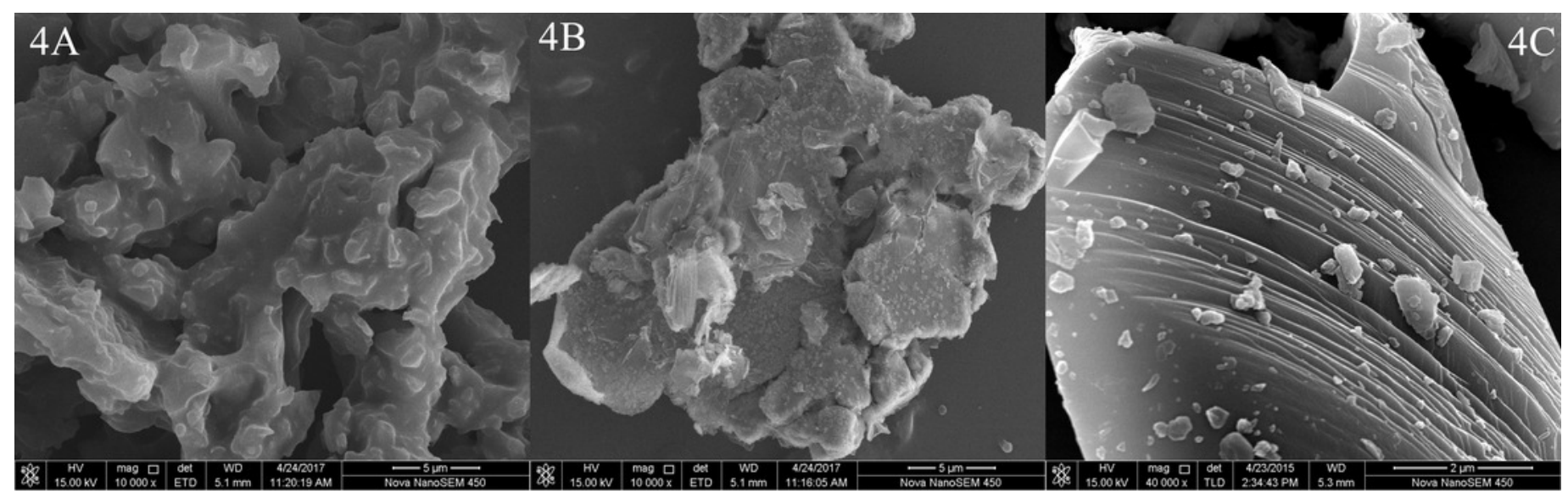


Figure 5

FTIR spectra of BC and Fe-BC500 (A), and MF (B) before and after adsorption of Cu and $\mathrm{Cd}$.
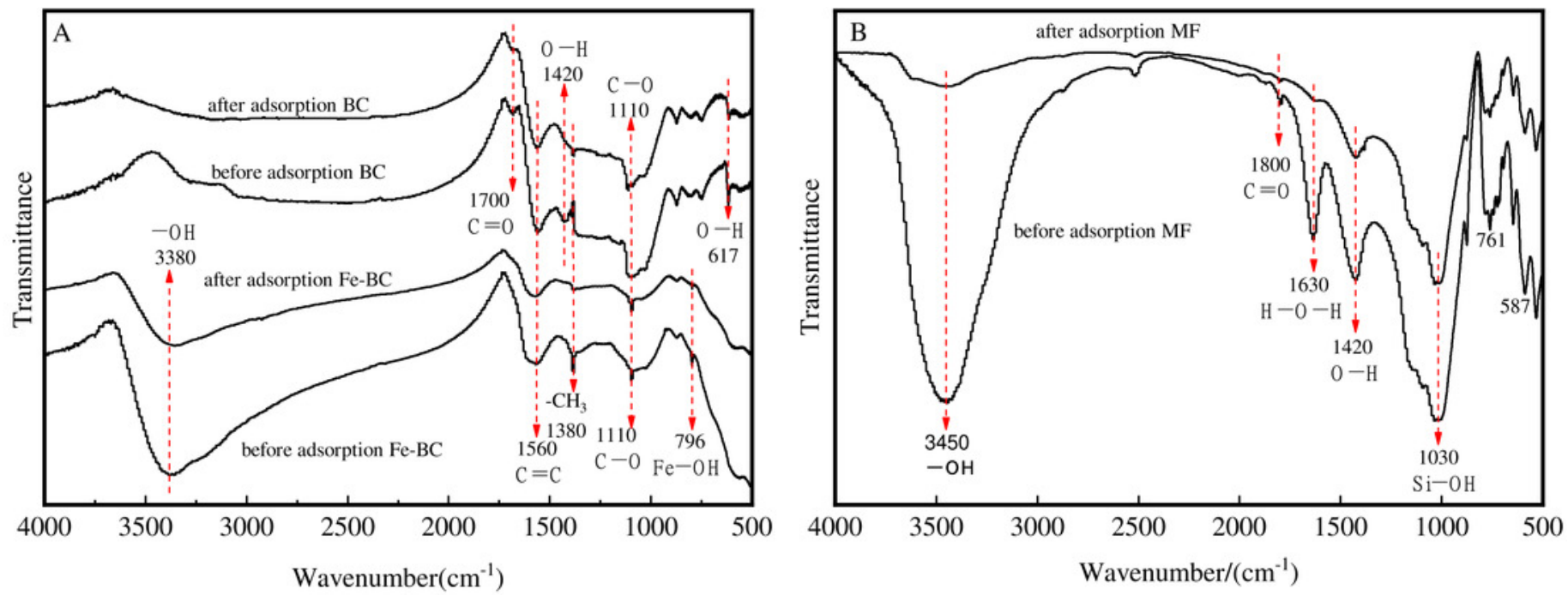
Figure 6

XRD patterns of $B C$ and Fe-BC (A) and MF (B) amendments before and after adsorption of $\mathrm{Cu}$ and $\mathrm{Cd}$.
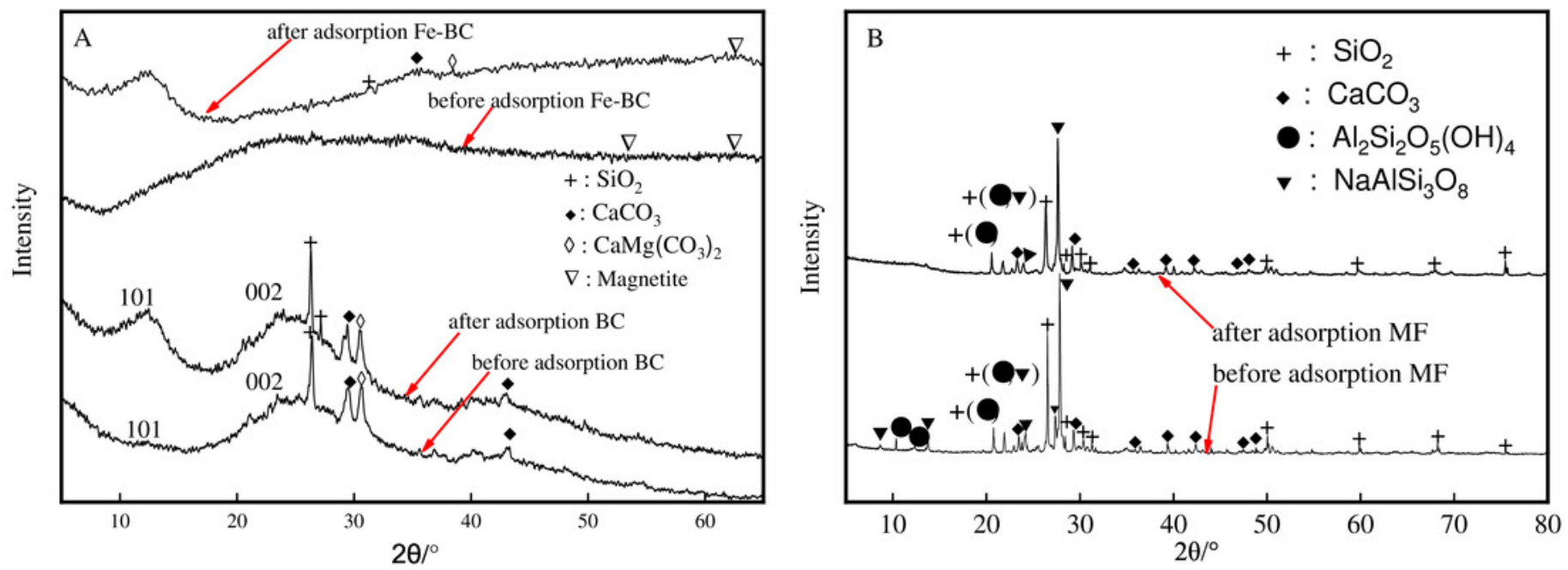
Figure 7

The heavy metal extraction fraction percentage in amendments after adsorption of $\mathrm{Cu}(\mathrm{A})$ and $\mathrm{Cd}(\mathrm{B})$.
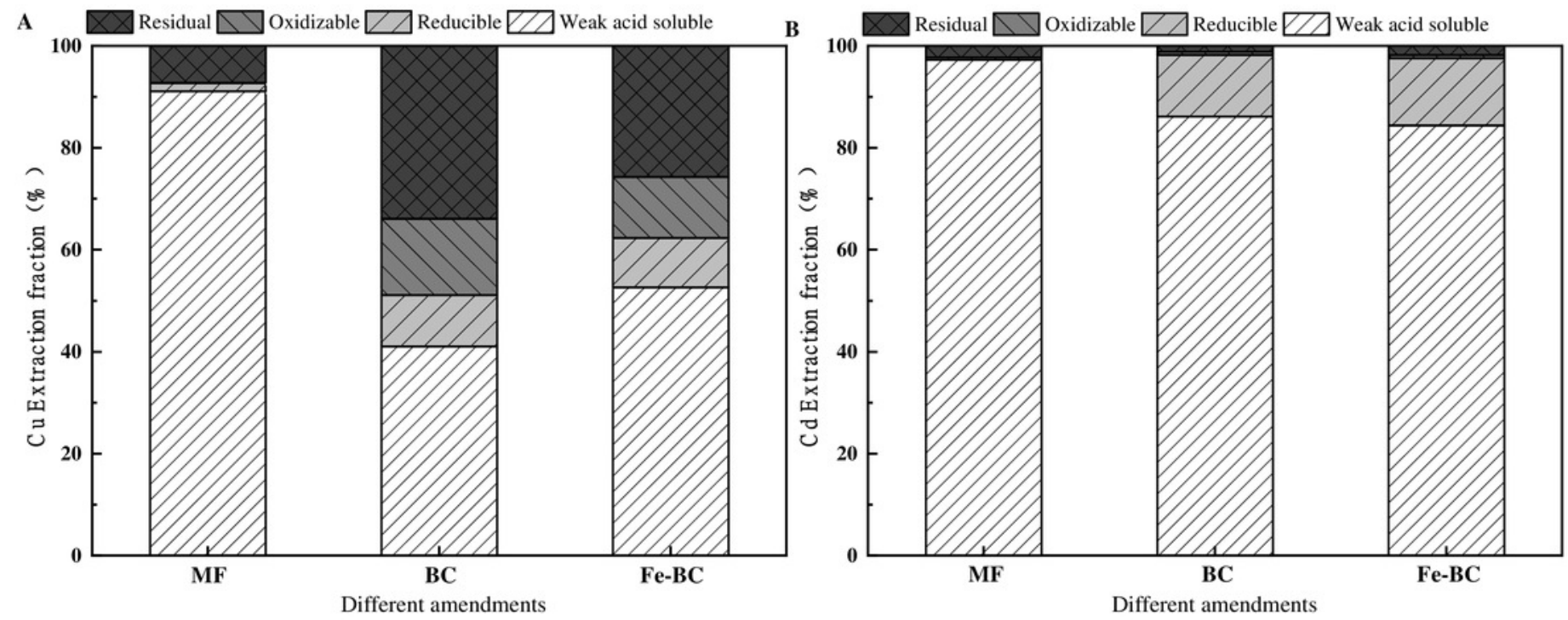
Figure 8

Effects of different amendments on the extract fraction of $\mathrm{Cu}(\mathrm{A})$ and $\mathrm{Cd}(\mathrm{B})$ in soil colloid
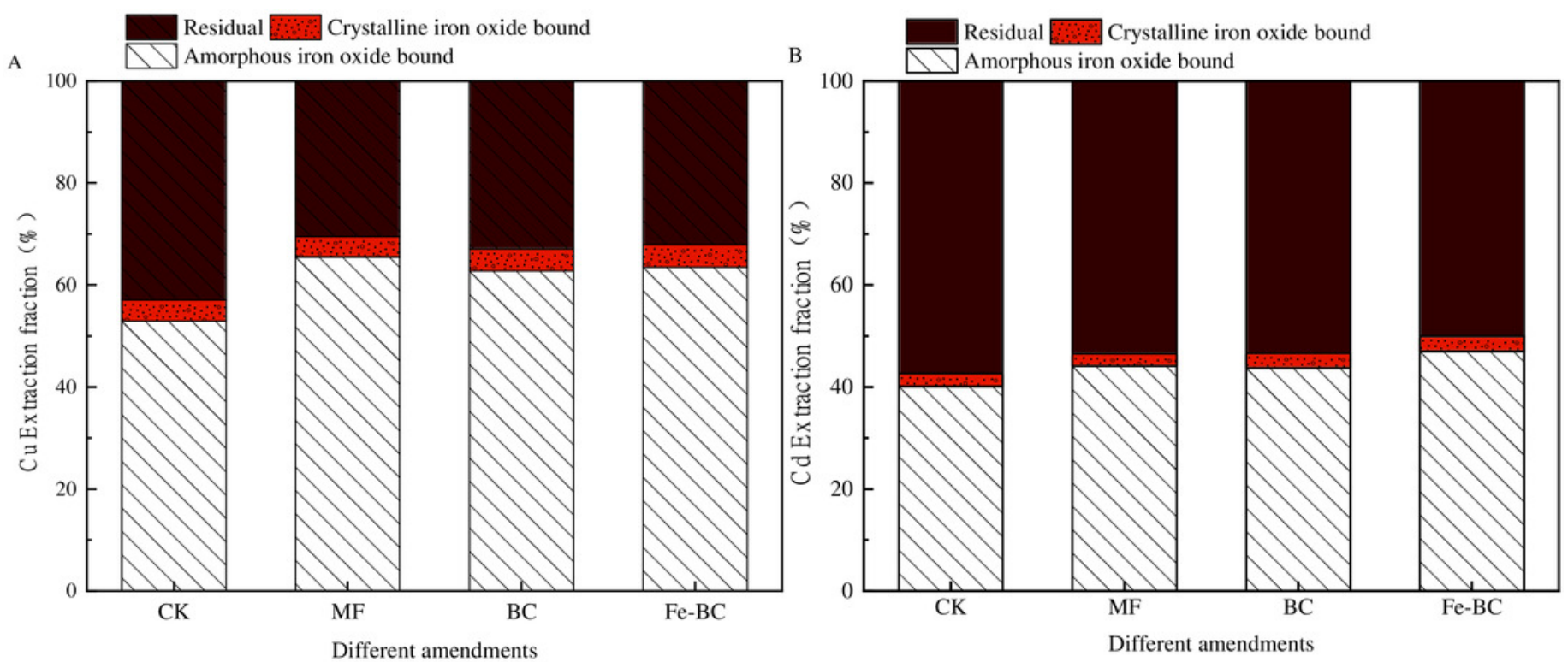